\title{
Stakeholder Activism, Managerial Entrenchment, and the Congruence of Interests between Shareholders and Stakeholders.
}

\author{
Giovanni Cespa ${ }^{\dagger}$ and Giacinta Cestone ${ }^{\ddagger}$
}

July 22, 2002

\begin{abstract}
We argue that when stakeholder protection is left to the voluntary initiative of managers, concessions to social activists and pressure groups can turn into a selfentrenchment strategy for incumbent CEOs. Stakeholders other than shareholders thus benefit from corporate governance rules putting managers under a tough replacement threat. We show that a minimal amount of formal stakeholder protection, or the introduction of explicit covenants protecting stakeholder rights in the firm charter, may deprive CEOs of the alliance with powerful social activists, thus increasing managerial turnover and shareholder value. These results rationalize a recent trend whereby wellknown social activists like Friends of the Earth and active shareholders like CalPERS are showing a growing support for each other's agendas.
\end{abstract}

Keywords: Corporate Governance, Managerial Entrenchment, Social Activists, Small Shareholders, Stakeholder Society

JEL Codes: G28, G34, G38

\footnotetext{
*We thank Ramon Caminal, Marco Pagano, Urs Peyer, Jean Tirole and Xavier Vives for helpful discussions, and Doug Cogan of the Investor Responsibility Research Center (IRRC) for providing information on social shareholder resolutions. The paper also benefited from seminar audience at IAE, Universitat Pompeu Fabra, INSEAD, and the 2002 ESSFM in Gerzensee. Giacinta Cestone acknowledges financial support from the TMR Network on "The Industrial Organization of Banking and Financial Markets in Europe," and the University of Salerno. Authors' addresses: Giovanni Cespa, Departament d'Economia i Empresa, Universitat Pompeu Fabra, Ramon Trias Fargas 25-27, 08005 Barcelona, Spain. E-mail: giovanni.cespa@econ.upf .es - Giacinta Cestone, Institut d'Analisi Economica (CSIC), Campus UAB, 08193 Bellaterra Barcelona, Spain. E-mail: giacinta.cestone@uab.es

${ }^{\dagger}$ Universitat Pompeu Fabra

‡Institut d’Anàlisi Econòmica (CSIC) and CEPR
} 


\section{Introduction}

When stakeholder protection is left to the voluntary initiative of managers, informal relations with stakeholders and social activists can turn into a powerful entrenchment strategy for incumbent CEOs. This is particularly true in countries and periods where social activism, political lobbying and media campaigns have the power to promote or disgrace top executives of large corporations. ${ }^{1}$ Inefficient managers have then a special motive for committing themselves to a socially responsible behavior that gains stakeholders' support. Explicit stakeholder protection - whether enforced by the law or by a mutually agreed contract between a firm's shareholders and its stakeholders - can break this implicit pact, thus favoring control contestability and managerial turnover.

We propose a simple model where stakeholders other than shareholders ${ }^{2}$ can affect the likelihood of CEO replacement, and incumbent CEOs can commit themselves (and not their firm) to a stakeholder-friendly behavior. This subtle self-entrenchment strategy becomes more appealing to CEOs when corporate law and the firm's charter promote independent boards, proxy fights and hostile takeovers. As to stakeholders, when deciding whether to support the incumbent CEO, they trade off the cost of a less talented manager against the benefit of managerial concessions. The latter are less valuable if stakeholders expect to receive a fair treatment independently of who runs the firm. Within this framework, we show the following four facts. First, when private benefits of control are high and stakeholder activism is effective, corporate governance reforms aimed at enhancing managerial turnover should be accompanied by an increase in explicit stakeholder protection. If not, they may simply spur more managerial concessions to stakeholders. Second, shareholder value may often be enhanced by the introduction of stakeholder protection rules that crowd out managerial concessions and make corporate officers less entrenched. Third, although stakeholders may support an inefficient CEO committed to a socially responsible behavior against an alternative manager, stakeholder welfare is always increasing in the degree of

\footnotetext{
${ }^{1}$ It is widely recognized that stakeholders enjoy substantial effective control on firms by the threat of costly boycotts and media campaigns (see Baron 2001, Feddersen and Gilligan 2000 and John and Klein 2001). In particular, social activists, local communities and unions often act as "white squires" to block hostile takeovers. The Krupp-Thyssen case reported by Hellwig (2000) provides an example of workers as successful white squires. The interference of other social activists in takeover contests is documented by DeAngelo and DeAngelo (1998), who comment on the environmentalist campaign set up against she 1986 hostile takeover of MAXXAM over Pacific Lumber Company.

${ }^{2}$ Namely, workers, consumers, local communities and potential pollutees. Although most of the literature has focussed on the relationship between firms and workers (see Blair, 1995, Blair and Roe, 1999, and Hansmann, 1996), the debate on the stakeholder society concept has unveiled the importance of other constituencies as well.
} 
control contestability. This is because CEOs who can rely on anti-takeover defenses and dominated boards do not need stakeholders' support to buttress their positions. Finally, CEOs are always opposed to any institutionalization of stakeholder protection which would deprive them of their grip on stakeholders.

Our work is motivated by a recent trend whereby social and environmental activists and shareholders are growing increasingly supportive of each other's agendas, as corroborated by the following stylized facts:

\section{Shareholders' recognition of stakeholders' rights.}

Mainstream shareholder activists and institutional investors are asking firms to produce timely information on environmental and social performance and even to link executive compensation to these measures. The Corporate Sunshine Working Group, an alliance between institutional investors, environmental organizations, unions and public interest groups, is asking the SEC to expand corporate social and environmental disclosure requirements. As reported by the Investor Responsibility Research Center (IRRC), resolutions filed by socially responsible shareholders are often endorsed by institutional shareholders that have long been associated with shareholder-value enhancing activism, like CalPERS. ${ }^{3}$ There are even cases where social activists and minority shareholders have shared the costs of resolutions and proxy fights to improve the firms' corporate governance and its commitment to stakeholders. $^{4}$

Social activists' interest for corporate governance issues.

Social and environmental activists are more and more involved in the corporate governance debate. Many activists have in fact joined forces with shareholders' lobbies to campaign against anti-takeover legislation, CEO-dominated boards and lenient auditors, issues that used to be well beyond the traditional social activism program. Business Ethics, a well-known publication on socially responsible business, ranks first the need for independent

\footnotetext{
${ }^{3}$ Activists are increasingly exploiting standard corporate governance tools (e.g., shareholder resolutions and proxy contests) to commit firms to a socially responsible behavior. As recently reported by The Economist (May the 10th, 2001) "Shareholder activism is not new. But the issues being put to the vote [at firms' annual meetings] are moving beyond corporate governance towards questions of social, environmental and ethical behaviour." For interesting evidence on shareholder activism on social issues, see IRRC (2000).

${ }^{4} \mathrm{~A}$ case in point is represented by the unusual proxy fight set up in 1999 against Charles Hurwitz, the C.E.O. of Maxxam Corporation, accused of breach of fiduciary duty by shareholders, and held responsible for Maxxam's 128 violations of environmental regulation and costly labor disputes. The fight was aimed at imposing an independent board of directors at Maxxam (with one director being a leading consumer rights advocate), and it was simultaneously supported by mainstream shareholder activists like CalPERS, by the Rose Foundation for the Communities and the Environment, and the United Steelworkers of America, all holding minority shares in the firm.
} 
auditors within its list of guidelines to reform US corporations. In a note dedicated to the use of shareholder resolutions by NGOs as a tool of pressure on corporations, Friends of the Earth reports that "socially-oriented shareholders often link social issues to corporate governance issues." The Rose Foundation for the Communities and the Environment has recently used its shareholdings in corporations to pressure in favor of social responsibility, but also for more independent boards. ${ }^{5}$

General contempt for corporate malpractices.

Recent corporate scandals have raised awareness among all constituencies that ill-managed corporations harm both their shareholders and other stakeholders at large. It is widely believed that Enron CEOs' did not only breach their fiduciary duty towards shareholders by misreporting earnings; they also deceived communities and workers by manipulating energy prices in California and getting rid of their shares right before the company collapsed. These considerations suggest that shareholders' and stakeholders' interests may be more congruent than received wisdom holds, to the extent that both have a common interest in favoring better management of corporations.

The paper contributes to the current debate on the stakeholder society (see Hellwig, 2000 and Tirole, 2001), trying to assess who has an interest in endorsing a stakeholder society concept, whereby managers are intended to have a multiple mission of aiming at both shareholder value and stakeholder welfare. We wonder whether both stakeholders and shareholders may not be better off when managers are bound to maximize shareholder value, while clear covenants restricting the firms' set of actions are established either by firm charters or by the law to rule out actions that may impose large negative externalities on stakeholders. Tirole (2001) argues that putting in place managerial incentives and control structures that implement the stakeholder society concept may be very costly. Our paper shows that the decision not to institutionalize stakeholder protection may prove even costlier, leaving managers with the monopoly of relationships with stakeholders. In other words, the lack of rules on corporate behavior is not always a synonymous for firm profitability and shareholder value; often, it is only an excuse for managerial discretion.

Our work is related to Pagano and Volpin (2002a), who analyze the behavior of incumbent managers and workers in a firm faced with a hostile takeover threat, and argue that incumbents are "natural allies" of workers: the former have an interest in offering long-term contracts to workers so as to discourage the takeover, while the latter are likely to support a lazy manager prone to low monitoring against a more efficient raider. In their paper,

\footnotetext{
${ }^{5}$ See respectively http://www. business-ethics.com, http://www.foe.org, http://www.rosefdn.org
} 
managerial effort is instrumental to reducing workers' wages, hence takeover gains occur via a reduction in stakeholder welfare. In Pagano and Volpin (2001) this has two natural implications. First, workers are always opposed to rules favoring control contestability. Second, incumbent managers can only gain (and shareholders lose) by an institutionalization of employment protection, to the extent that long term labor contracts can be used as poison pills to deter takeovers. We derive opposite predictions in a model where raiders increase the corporate pie rather than simply redistribute it from stakeholders to shareholders. ${ }^{6}$ Indeed, it is this feature of our model that leaves room for a "congruence of interests" between shareholders and stakeholders over the security of managerial jobs and the formal protection of stakeholders.

The paper is related to the recent literature on the political economy of corporate governance (see Pagano and Volpin, 2002b and Perotti and von Thadden, 2002 for the relevant references), to the extent that its results can be applied to a political economy framework to study how corporate governance and stakeholder protection laws are simultaneously determined. Our results also relate to the well-known Porter hypothesis (see Porter and van der Linde, 1995) that environmental regulation enhances innovation. This conjecture has been recently formalized in a mechanism design model by Ambec and Barla (2001), who argue that environmental regulation reduces agency costs. Notice that while their work relies on the crucial assumption that more polluting technologies are also costlier, we argue that environmental regulation may benefit shareholders even in cases where polluting technologies are more profitable.

The paper proceeds as follows. In section 2 we set up the basic model. We rule out potential collusion between incumbent managers and stakeholders, and study how shareholder value and stakeholder welfare are affected by stakeholder protection and corporate governance. In section 3, we assume that incumbent managers can commit to a stakeholderfriendly behavior, in order to obtain stakeholders' support against a replacement attempt. We study under which conditions an implicit agreement between managers and stakeholders arises. In section 4, we analyze shareholders', stakeholders' and incumbent managers' preferences over corporate governance and explicit stakeholder protection. In section 5 we briefly discuss two applications of our result.

\footnotetext{
${ }^{6}$ Whether takeovers can only create value by reducing stakeholder welfare is largely an empirical question: while evidence on the effects on the wage bill is mixed (see Becker, 1995 and Bhagat, Shleifer and Vishny, 1990, but also Jarrell, Brickley and Jeffry, 1988 and Rosett, 1990) casual observations suggest that hostile takeovers may well benefit natural stakeholders like consumers and potential pollutees. See also footnote 12 .
} 


\section{The model}

Consider a firm run by a manager (I) enjoying a large private benefit of control $\gamma$ from running the firm. A fraction of shares $\alpha$ is held by the manager, while $(1-\alpha)$ shares are dispersed among small shareholders (SH). Dispersed shareholders have no control over the firm's course of action. The firm generates both a monetary profit, which accrues to its owners, and a non-monetary externality on its other stakeholders (ST). We may think of natural stakeholders like potential pollutees and environmentalists, customers or local communities. Stakeholders derive no utility from money. All agents in the model are riskneutral.

\section{Projects}

The firm's manager can either run the status quo project, or try to improve on it by discovering a new project. The status quo project (project zero) is highly disliked by both shareholders and stakeholders, in that it yields no profits and no private benefits to stakeholders. There are also $N$ a priori identical projects, $k \in\{1,2, \ldots, N\}$, which yield a verifiable monetary profit $R$ with probability $p+\tau_{k}$ (and zero with probability $\left(1-p-\tau_{k}\right)$ ), and a non-verifiable private benefit to stakeholders $B_{k}$. It is known that $(N-2)$ projects are worse than project 0 for both SH and ST, and that at least one of them has disastrous consequences for both. The only two "relevant projects" generate the following expected monetary payoffs to shareholders and externalities on stakeholders:

\begin{tabular}{|c|c||c|}
\hline 1 & 2 & probability \\
\hline \hline$(p+\tau) R, B$ & $p R, 0$ & $\lambda$ \\
$(p+\tau) R, 0$ & $p R, B$ & $1-\lambda$ \\
\hline
\end{tabular}

The shareholder's preferred project succeeds with probability $p+\tau$; the stakeholders' preferred project exerts a positive externality $B$ on stakeholders. $B$ can be thought of as the foregone pollution with respect to the status quo project, the value of preserved employment for a local community, or the value of additional product safety for consumers. With probability $\lambda$ the shareholders' and the stakeholders' preferred projects coincide; with probability $(1-\lambda)$, the shareholder's preferred project yields no private benefit to stakeholders, while the stakeholder's preferred project only succeeds with probability $p$. We assume that $\lambda$ belongs to $(0,1)$. $\lambda$ measures the congruence of interests between shareholders and stakeholders; alternatively, $(1-\lambda)$ captures the trade off between profit maximization and 
social/environmental objectives. ${ }^{7}$

\section{Managerial talent}

The payoffs attached to new projects are unknown unless further investigation is carried out by the firm's CEO. A manager $i$ learns the new projects' payoffs with probability $\theta_{i}$, in which case she selects one. With probability $\left(1-\theta_{i}\right)$, the manager does not learn anything; hence, she optimally decides to run the status quo project. We define $\theta_{i}$ to be the managerial talent for innovation. The incumbent CEO has talent $\theta_{I}$. A better alternative manager, with talent $\theta_{R}>\theta_{I}$ is known to exist. However, she still has to be identified in the managerial labor market.

\section{CEO replacement attempts}

We assume that with probability $\pi \in(0,1)$ the board of directors or a coalition of shareholders identifies the alternative manager (or else, the latter realizes that it can improve the firm's value and launches a hostile takeover on the firm). $\pi$ thus represents the extent of effective competition in the managerial labor market, both at the firm level and at the economy-wide level. $\pi$ is likely to be high when corporate law and the firm's charter promote independent boards and proxy fights, and when anti-takeover defenses are not allowed.

\section{Stakeholder activism}

When a replacement attempt occurs, stakeholder representatives such as social and environmental activists or local communities may side with the incumbent CEO to make sure that she is not replaced. Activists dispose of powerful tools in this respect: they may start a media campaign and even threaten a boycott in case the replacement occurs; alternatively, by exerting pressure on political leaders to back their cause, they can create an adverse political climate to the proxy fight or the takeover (Hellwig, 2000). ${ }^{8}$ If undertaken, a stakeholder campaign succeeds with probability $a$ in deterring CEO replacement, where $a \in(0,1)$, and fails with probability $(1-a) .{ }^{9}$ We assume that a stakeholder campaign is costless; the cost of campaigning could be taken into account in the model without changing its qualitative results.

\footnotetext{
${ }^{7}$ This modeling choice follows Aghion and Tirole (1997)'s lines in capturing the idea that parties in a relationship may have a partial congruence of interests over the course of action to be taken.

${ }^{8}$ Hellwig (2000) argues that organized stakeholders like unions and local communities often act as "white squires" to block hostile takeovers. In recent years, intense media campaigns against corporate takeovers have been led by social and environmental activists. See for instance DeAngelo and DeAngelo (1998) for a report on the environmentalist campaign against the 1986 hostile takeover of Maxxam over Pacific Lumber Company.

${ }^{9}$ For the sake of simplicity, we assume that stakeholders do not choose the intensity of the campaigning activity, but only whether to campaign or not, hence $a$ is an exogenous parameter.
} 


\section{Formal stakeholder protection}

The firm's choice of a course of action may be constrained by stakeholder protection rules. We model this by assuming that - once projects are discovered - with probability $x_{r}$ the manager is obliged to pick the project yielding $B$ to stakeholders, independently of whether this maximizes profits. This assumption has two interpretations. (a) Legal Stakeholder Protection - A regulatory agency with the unique objective of maximizing stakeholder welfare, and deriving no utility from money, has the formal right to make binding recommendations over the choice of projects (for instance, it may rule out projects requiring a polluting production process or impose a minimal standard of safety for consumers and workers). However, it effectively exerts this right only if it is informed about the projects' payoffs, ${ }^{10}$ which happens with probability $x_{r} \in(0,1)$. We think of $x_{r}$ as being inversely correlated to the authority's degree of overload, and directly related to the quality of its staff and the resources on which it can draw to pursue its investigations and enforce its decisions. ${ }^{11}$ (b) Contractual Stakeholder Protection - A mutually agreed contract between the firm's owners and its stakeholders includes covenants ruling out projects that yield very low outcomes to stakeholders (i.e., $B_{k}=0$ ). The extent to which these covenants are enforced $\left(x_{r}\right)$ depends in turn on the amount of hard information that the firm is obliged to disclose to stakeholder representatives. Firms' agreements with NGOs and so-called "ethic indexes" to comply with a minimal level of environmental performance and labor safety, and to produce reliable information on these dimensions, are an example of such covenants.

\section{Timing}

The timing of events is described in figure 1 . At $t=1$, with probability $\pi$ an alternative manager challenges the incumbent CEO. If so, stakeholders may campaign and threaten a boycott against the potential new management. The campaign succeeds with probability a. At $t=2$, the manager who is in control learns the payoffs and selects a new project with probability $\theta_{i}(i=I, R)$. If stakeholder protection rules or covenants are enforced, the manager has to comply with them; otherwise, she is free to choose her most favored project. At $t=3$, monetary payoffs accrue to shareholders and the manager (who also enjoys the

\footnotetext{
${ }^{10}$ This descends from the assumptions that some projects yield a negative payoff to stakeholders, and that projects all look alike ex-ante.

${ }^{11}$ This is a reasonable description of what determines the extent of regulatory agencies' interference in firms' activity. For instance, environmental activists consider the Environmental Protection Agency's budget as a crucial variable to be monitored. Friends of the Earth, a well-known US environmentalists organization, has recently stressed how the Bush administration's cuts to the EPA budget may damage EPA's ability to make and enforce recommendations and environmental laws. Among all budget cuts, the most criticized are those to the Office of Science and Technology, which provides scientific backbone to EPA's regulatory decisions and actions, and those to EPA's enforcement office (see http://www.foe.org).
} 
private benefit of control $\gamma$ ), while stakeholders enjoy the private benefits generated by the firm's activity. In section 3 , we will assume that at an initial date $t=0$ the incumbent CEO can make a personal investment to credibly commit herself to a "stakeholder-friendly" behavior, so as to establish a privileged relationship with powerful stakeholder activists.

Figure 1: The timeline

\begin{tabular}{|c|c|c|c|}
\hline 0 & 1 & 2 & 3 \\
\hline $\begin{array}{l}\text { (Incumbent CEO } \\
\text { invests in stake- } \\
\text { holder relation.) }\end{array}$ & $\begin{array}{l}\text { Replacement attempt } \\
\text { (probability } \pi \text { ). Stake- } \\
\text { holders campaign or } \\
\text { not }\end{array}$ & $\begin{array}{l}\text { Controlling manager } \\
\text { learns payoffs and picks } \\
\text { project with prob. } \theta_{i}, \\
\text { complies with regulation } \\
\text { with prob. } x_{r} ; \text { with } \\
\text { prob. } 1-\theta_{i} \text { implements } \\
\text { the status quo. }\end{array}$ & Pay-offs accrue. \\
\hline
\end{tabular}

\subsection{The benchmark: no managerial entrenchment}

In this section we analyze the impact of the quality of corporate governance rules favoring managerial turnover $(\pi)$ and the extent of formal stakeholder protection $\left(x_{r}\right)$ on shareholder value, stakeholder welfare and the incumbent's rents, when incumbent CEOs cannot entrench themselves at $t=0$.

In this benchmark case, at $t=2$, whenever free from the regulatory interference, any manager chooses the project which maximizes equity value. As the incumbent manager is not more lenient to favor stakeholders than a raider is, ceteris paribus, stakeholders benefit when the more efficient manager takes over:

$$
\theta_{R}\left[x_{r} B+\left(1-x_{r}\right) \lambda B\right]>\theta_{I}\left[x_{r} B+\left(1-x_{r}\right) \lambda B\right] .
$$

Hence, they optimally decide not to support the incumbent CEO at $t=1$. Given this, 
shareholder value is:

$$
\begin{aligned}
& V_{S H}\left(\pi, x_{r}\right)= \\
& \quad=\pi \theta_{R}\left[x_{r}(p+\lambda \tau)+\left(1-x_{r}\right)(p+\tau)\right] R+(1-\pi) \theta_{I}\left[x_{r}(p+\lambda \tau)+\left(1-x_{r}\right)(p+\tau)\right] R \\
& \quad=\left[\theta_{I}+\pi\left(\theta_{R}-\theta_{I}\right)\right]\left[p+\tau-(1-\lambda) \tau x_{r}\right] R,
\end{aligned}
$$

where expected project returns under the relevant regulatory constraints are multiplied by the average managerial quality. Stakeholder welfare also depends on project choice and average managerial quality:

$$
\begin{aligned}
W_{S T}\left(\pi, x_{r}\right) & =\pi \theta_{R}\left[x_{r}+\left(1-x_{r}\right) \lambda\right] B+(1-\pi) \theta_{I}\left[x_{r}+\left(1-x_{r}\right) \lambda\right] B \\
& =\left[\theta_{I}+\pi\left(\theta_{R}-\theta_{I}\right)\right]\left[\lambda+(1-\lambda) x_{r}\right] B
\end{aligned}
$$

Finally, the incumbent manager's utility is:

$$
\begin{aligned}
U_{I}\left(\pi, x_{r}\right) & =(1-\pi)\left[\gamma+\theta_{I}\left(p+\tau-(1-\lambda) \tau x_{r}\right) \alpha R\right]+\pi \theta_{R}\left(p+\tau-(1-\lambda) \tau x_{r}\right) \alpha R \\
& =\theta_{R}\left(p+\tau-(1-\lambda) \tau x_{r}\right) \alpha R+(1-\pi)\left[\gamma-\Delta \theta\left(p+\tau-(1-\lambda) \tau x_{r}\right) \alpha R\right] .
\end{aligned}
$$

An incumbent $\mathrm{CEO}$ with a high enough stake might be better off when she is replaced, to the extent that the additional value of her stake offsets the lost benefits of control. Here, however, we focus on CEOs whose private benefits of control are sufficiently large relative to their equity stake that they always want to stay on (i.e., $\gamma>\Delta \theta(p+\tau-(1-\lambda) \tau) \alpha R)$. This implies that low-talented incumbent CEOs are always opposed to good corporate governance.

In table 1 we display the preferences of each type of agent (stakeholders, shareholders, and the incumbent $\mathrm{CEO}$ ) with respect to corporate governance rules reducing the security of managerial jobs and to formal stakeholder protection:

Table 1: Effect of an increase in $\pi$ and $x_{r}$ on agents' utilities

\begin{tabular}{|c||c|c|}
\hline & $\pi$ & $x_{r}$ \\
\hline \hline ST & + & + \\
SH & + & - \\
I & - & - \\
\hline
\end{tabular}

Notice that while shareholders and stakeholders have dissonant preferences over the extent of stakeholder protection, they both are better off under a tighter corporate governance regime. Indeed - although their views may differ on which is the best project to adopt - both 
stakeholders and shareholders have a common interest in enhancing managerial turnover. The reason for this is that shareholder value need not necessarily be created at the expense of stakeholder welfare; indeed, it is often the case that more efficient and innovative managers, by increasing the size of the corporate pie, benefit both shareholders and stakeholders. ${ }^{12}$

In this "first best" scenario, shareholder value is maximized when $\pi$ and $x_{r}$ are respectively close to 1 and 0 , that is, when the quality of corporate governance is high while stakeholder protection is minimized. In what follows, we allow the incumbent CEO to make binding commitments vis-à-vis stakeholders, so that stakeholder activists will have an incentive to campaign against the potential new manager. As we will see, this changes dramatically shareholders' preferences over corporate governance and stakeholder protection.

\section{Stakeholder activism and managerial entrenchment}

Under the existing corporate governance regime, the incumbent manager faces a probability $\pi$ of being replaced. Hence, at $t=0$ she may try to entrench herself by building a privileged relationship with the firm's stakeholders. There are several ways to achieve such a commitment. The manager can make an early investment in "environmental human capital" so as to gain expertise in implementing environmentally-friendly projects. ${ }^{13}$ She can spend long hours gathering the advice of, and building relationships with, NGO representatives, local communities and environmentalists. More generally, she can develop a reputation for being lenient to stakeholders' requests.

We model this idea in the following way. Suppose that implementing any project $k \in$ $\{0,1,2, \ldots, N\}$ imposes a private cost $c$ on management. At $t=0$, however, the incumbent CEO can make an observable investment in expertise to reduce such a cost. In particular,

\footnotetext{
${ }^{12}$ Indeed, although many hint at a "natural alliance" between stakeholders and inefficient CEOs (see for instance Hellwig, 2000), to us it is not obvious that stakeholders need benefit from managerial inefficiency. For instance, consumers may be better off when a more innovative manager takes over to improve the firm's products. Potential pollutees may well be more aligned to shareholders concerned with future environmental liabilities, rather than to a myopic manager with poor incentives to invest in discovering green production processes. For instance, and against common wisdom, hostile takeovers enhancing efficiency in the oil industry have led to curtailment of excessive exploration. Probably, it is not managerial inefficiency per se that pleases stakeholders; managerial concessions do.

${ }^{13}$ Investment in "green expertise" is becoming a fashionable strategy for many corporate officers. In an interview with McKinsey consultants, the C.E.O. of Dow Chemical Company (a leader in the voluntary adoption of environmentally-friendly strategies) stated that he allocates about 25 percent of his time to handling environmental issues. He also reported on the firm's dialogue with stakeholders: "[we created] a panel for the corporation on a worldwide basis. It includes academics, environmentalists, a former EPA director, (...) and it worked: we have learnt from the panel, and they have learnt from us." ("What is Environmental Strategy?", The McKinsey Quarterly, 1993, 4: 53-68)
} 
she can invest $x_{c}$ at cost $K x_{c}$, and learn with probability $x_{c}$ how to implement stakeholderfriendly projects yielding a private benefit $B$ to stakeholders (e.g., projects requiring cooperation from the local community, pollution-free projects, etc.); in this case the private cost of implementing such projects is reduced to zero. Investing in the relationship with stakeholders and local communities requires time; hence, this investment is not feasible to outside managers. We assume that $K=c$, which implies that the investment is never profitable unless it is part of an entrenchment strategy. We also assume:

\section{Assumption 1}

$$
\alpha \tau R<c .
$$

This assumption implies that when an investment $x_{c}$ is undertaken, with probability $x_{c}$ the incumbent manager's preferences are congruent with stakeholders': the manager picks the stakeholders' favorite project even at the expense of monetary profits. With probability $\left(1-x_{c}\right)$, the manager gains no expertise and her preferences are congruent with shareholders'; hence, she only picks the stakeholders' favorite project with probability $\lambda$. This directly implies the following lemma:

Lemma 1 The degree of congruence between the incumbent manager's and the stakeholders' objectives is measured by $\lambda+(1-\lambda) x_{c}$; it increases from $\lambda$ to 1 as the "stakeholder-specific investment" $x_{c}$ is raised from 0 to 1 .

$x_{c}$ thus measures the amount of managerial concessions to stakeholders. At $t=1$, stakeholders are willing to support the incumbent CEO provided $x_{c}$ satisfies the following constraint:

$$
\theta_{I}\left(1-x_{r}\right)(1-\lambda) B x_{c} \geq\left(\theta_{R}-\theta_{I}\right)\left[\lambda+(1-\lambda) x_{r}\right] B
$$

that is, the concessions to be expected under the incumbent management outweigh the cost for stakeholders of bearing a less efficient manager. This constraint implies that managerial concessions must lie above a threshold $\underline{x_{c}}\left(x_{r}\right)$. Notice that $\underline{x_{c}}\left(x_{r}\right)$ is increasing in $x_{r}$ : if stakeholders' interests are protected by regulation or by an explicit contractual agreement between the stakeholders and the firm, then stakeholders are more hardly convinced to back an inefficient CEO.

A self-entrenchment strategy whereby the CEO invests $x_{c} \geq \underline{x_{c}}\left(x_{r}\right)$ in stakeholder relationships is profitable if and only if: 


$$
\begin{aligned}
\pi a\left\{\gamma-c-\alpha R \Delta \theta\left[(p+\tau)-(1-\lambda) \tau x_{r}\right]\right\} & \geq \\
& {[1-\pi(1-a)]\left[\alpha R \theta_{I}\left(1-x_{r}\right)(1-\lambda) \tau\right] \underline{x_{c}}\left(x_{r}\right) }
\end{aligned}
$$

that is, the higher expected rents enjoyed by the incumbent CEO owing to self-entrenchment outweigh the cost of the pro-stakeholder concessions. A first inspection of condition (2) allows us to state the following lemma:

Lemma 2 The CEO's incentives to self-entrench by establishing stakeholder relationships are stronger the tougher is the replacement threat (the higher is $\pi$ ) and the more effective is stakeholder activism (i.e., $a$ is large).

When good corporate governance deprives managers of standard tools to protect their jobs (such as anti-takeover defenses and CEO-dominated boards) CEOs turn to subtler ways to stay in power. As the effectiveness of social activists' campaigns increases, building a relationship with stakeholder representatives may become a powerful self-entrenchment tool.

Let us define:

$$
\Gamma \equiv \frac{(\gamma-c)}{\alpha R}
$$

which measures the relative importance of private benefits of control versus monetary returns in the CEO's objective function. This variable is of crucial importance to our results; indeed, only when control benefits are large enough compared to the managerial equity stake, is the CEO willing to resist a replacement, even undergoing the cost of pro-stakeholder concessions. ${ }^{14}$

The following lemma establishes how, for any intensity of the managerial replacement threat, an appropriate level of stakeholder protection can counter the CEO's entrenchment strategy:

\footnotetext{
${ }^{14}$ One may argue that increasing the CEO's equity stake $\alpha$ would eliminate the incumbent's incentive to resist a replacement. Hence, our results would depend on $\alpha$ being an exogenous variable in the model. Our answer is that even if $\alpha$ was endogenous, it could still be too costly to discourage managerial entrenchment by raising the CEO equity share. Notice that if large equity stakes were an effective, cheap instrument to deter managerial entrenchment, we would not observe top executives pressuring against corporate governance reforms that make control contestable, and engaging in creative self-entrenchment strategies, as we in fact do. See also Shleifer and Vishny (1988) for a discussion of reasons why many top executives own relatively little equity in the firms they run.
} 
Lemma 3 For any $\pi \in(0,1)$, there exist $\Gamma_{o}(\pi), \Gamma_{1}(\pi)$ such that for $\Gamma_{o}(\pi)<\Gamma<\Gamma_{1}(\pi)$, $\widehat{x}_{r}(\pi) \in(0,1)$ is the threshold level of stakeholder protection above which the incumbent CEO's entrenchment strategy becomes unprofitable. The threshold $\widehat{x}_{r}$ is increasing in $\pi$ and $\Gamma$, and decreasing in $\Delta \theta$.

Proof. See the appendix.

Figure 2 depicts the function $\widehat{x}_{r}(\pi)$ in the space $\left(\pi, x_{r}\right)$. Above the $\widehat{x}_{r}(\pi)$ locus, the incumbent CEO never invests in stakeholder relationships. This is either because poor corporate governance rules (low $\pi$ ) makes it easy for the CEO to preserve her job, or because explicit stakeholder protection $\left(x_{r}\right.$ high) makes stakeholders value less managerial concessions. Indeed, when faced with a potential alliance with the incumbent management, stakeholders trade off the benefit of managerial concessions against the cost of a less innovative management: if they expect to receive a good treatment independently of who runs the firm, they do not want to "strike" an implicit alliance with the incumbent CEO.

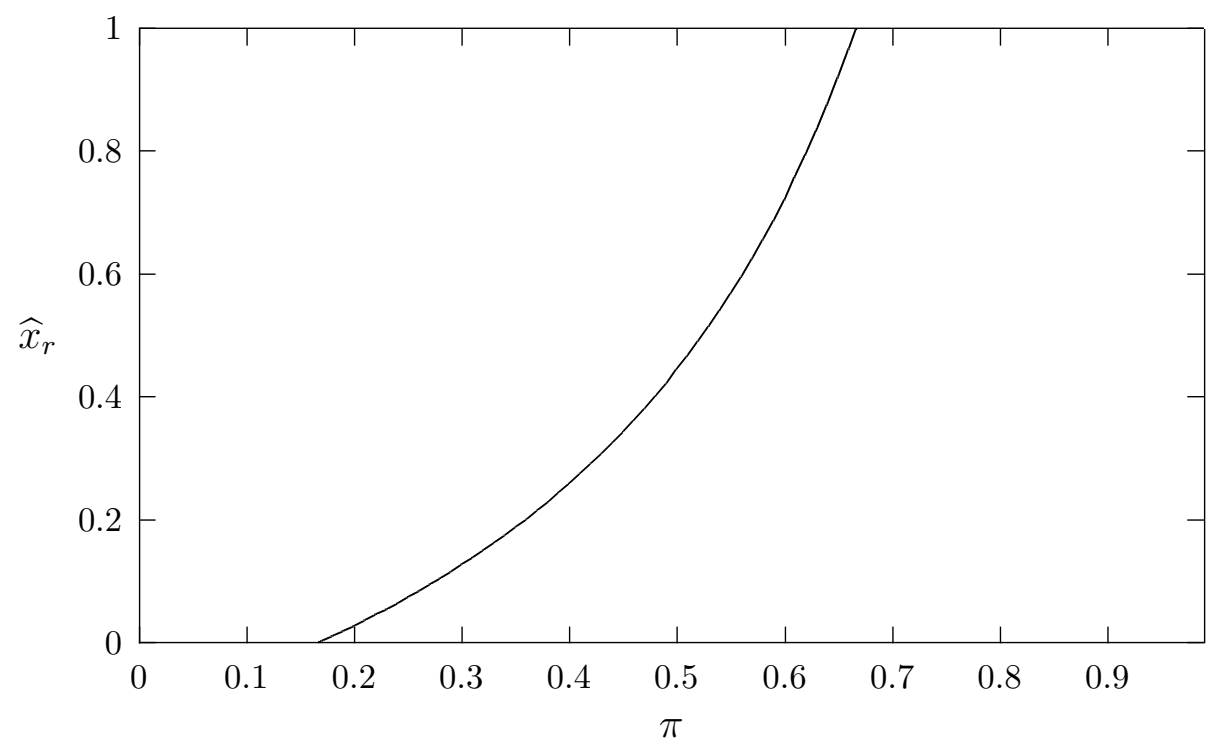

Figure 2: The function $\widehat{x}_{r}$.

Remark 1 The fact that the locus $\widehat{x}_{r}(\pi)$ is increasing in $\pi$ suggests that when stakeholder activism is very effective, corporate governance reforms aimed at enhancing managerial turnover should be accompanied by an increase in explicit stakeholder protection. If not, they may simply spur more managerial concessions and stakeholder activism. 
Assume that $\pi$ and $x_{r}$ lie below the $\widehat{x}_{r}(\pi)$ locus. Then the incumbent CEO commits to a protection of stakeholders' interests which goes beyond that to which the firm by itself is committed. ${ }^{15}$ If the gains from this implicit alliance are evenly split between the CEO and stakeholders, then the level of pro-stakeholder concessions $x_{c}^{*}$ equals the Nash bargaining solution:

$$
x_{c}^{*}=\frac{a \Delta \theta B\left(\lambda+(1-\lambda) x_{r}\right)+\pi a \alpha R\left(\Gamma-\Delta \theta\left(p+\tau-(1-\lambda) x_{r} \tau\right)\right)}{\theta_{I}\left(1-x_{r}\right)(1-\lambda)(a B+(1-\pi(1-a)) \tau \alpha R)} .
$$

Straightforward calculations show that $\left(\partial x_{c}^{*} / \partial \pi\right)>0,\left(\partial x_{c}^{*} / \partial x_{r}\right)>0$ and $\left(\partial x_{c}^{*} / \partial \lambda\right)>0$. Intuitively, a tougher replacement threat (e.g., an independent board or a ban on antitakeover defenses) makes the incumbent manager more willing to relinquish concessions to stakeholders in order to preserve control. The incumbent manager is also forced to larger concessions when a larger degree of stakeholder protection improves stakeholders' welfare under the alternative manager.

\section{Who benefits from good corporate governance and explicit stakeholder protection}

We now build on the previous section to analyze the impact of corporate governance regulation enhancing managerial turnover $(\pi)$, and of explicit stakeholder protection $\left(x_{r}\right)$, on shareholder value, stakeholder welfare and CEOs' rents. We argue that stakeholders and shareholders may to some extent have congruent preferences over both issues.

\subsection{Shareholder value, managerial replacement threats, and stake- holder protection}

In our model, small shareholders completely delegate control to managers, and an active market for corporate control ensures that inefficient managers are replaced. If stakeholder activism can impair the functioning of this market, incumbent CEOs have an incentive to "bribe" stakeholders by committing to less efficient project choices. This potential alliance changes dramatically shareholders' preferences over corporate governance regulation and legal stakeholder protection, as the following proposition shows.

\footnotetext{
${ }^{15}$ Corporate officers engaged to a socially responsible behavior insist on this voluntary compliance to an "over-protection" of stakeholders' interests. In a recent McKinsey report on environmental strategy, Dave Buzzelli, vice-president of the Environment, Health and Safety department of Dow Chemical Co., claims that "[Dow Chemical's] responses [to environmental concerns] go beyond compliance with current mandates and address global environmental issues on a proactive, voluntary basis." ("What is Environmental Strategy?", The McKinsey Quarterly, 1993, 4: 53-68)
} 
Proposition 1 Suppose managerial entrenchment is to be countered. Then, if the incumbent's control benefits are large $(\Gamma>\Delta \theta(p+\tau(1-\lambda)))$, shareholder value is concave in $\pi$. It is maximized when the managerial replacement threat is $0<\pi^{*}<<1$, and a minimal level of formal protection $\widehat{x}_{r}\left(\pi^{*}\right) \in(0,1)$ is provided to stakeholders. $\pi^{*}$ is decreasing in $\Gamma$ and $a$.

\section{Proof. See the appendix.}

Notice that, in contrast with section 2.1, when managers can entrench themselves through a stakeholder-friendly behavior shareholder value is a concave function of $\pi$. Thus, shareholders' interests are best served when competition in the managerial labor market is not too high (i.e. $\pi$ is strictly lower than 1 ). This is so as by lemma 3 countering managerial entrenchment when $\pi$ is high may prove very costly (i.e. require setting very strong stakeholder protection rules).

The following two examples show that depending on parameter values shareholders have two ways of countering managerial entrenchment. In the first example, where $a$ and $\Gamma$ are not too large, a high level of legal stakeholder protection (i.e., $x_{r}$ "large") can be associated to a tough replacement threat ( $\pi$ "large"), so that stakeholders are led to trust the alternative manager. The cost imposed on profits by stakeholder protection is outweighed by the higher expected managerial quality induced by managerial turnover. Notice that in example 1, the corporate pie (inclusive of stakeholder welfare) is increased at the expense of incumbent managers, though some shareholder value must be sacrificed to guarantee a minimal amount of welfare to stakeholders.

The above solution may become very costly, however, when stakeholders campaigns are very effective ( $a$ close to 1 ), and managers value much their private benefits of control $(\Gamma$ "large"), as in example 2. Indeed, stakeholders are easily lured by incumbent's large concessions. In such case, shareholder value is maximized by insulating CEOs from a replacement threat (i.e., setting $\pi$ low) and giving poor formal protection to stakeholders. Incumbent managers, who do not need stakeholders' support to buttress their positions, make few concessions to stakeholders; their preferences on projects are then more aligned with shareholder value. ${ }^{16}$ In example 2 , shareholder value is preserved by leaving rents to incumbent managers. Hence, the corporate pie (inclusive of stakeholder welfare) is reduced as average managerial quality is lower, but shareholder value is increased at the expense of stakeholder

\footnotetext{
${ }^{16}$ The idea that boards may prevent inefficient entrenchment strategies simply by "granting the CEO some insulation from competition for his job" has been often advanced in the corporate governance literature. See for instance Shleifer and Vishny (1989).
} 
welfare.

Example 1 In figure 3 we set $\theta_{I}=.1, \theta_{R}=.5, \alpha=.5, p=.5, \tau=.5, \lambda=.7, a=.4, B=2$ and $\Gamma=0.8$. With these parameters $\pi^{*}=0.44$ and $\widehat{x}_{r}\left(\pi^{*}\right)=0.47$.

Example 2 In figure 4 we keep the same data of example 1 but assume that both the stakeholder ability at affecting the replacement decision, and the incumbent control benefits are higher (i.e. we set $a=.8$ and $\Gamma=2$ ). In this case: $\pi^{*}=0.038$ and $\widehat{x}_{r}\left(\pi^{*}\right)=0.063$.

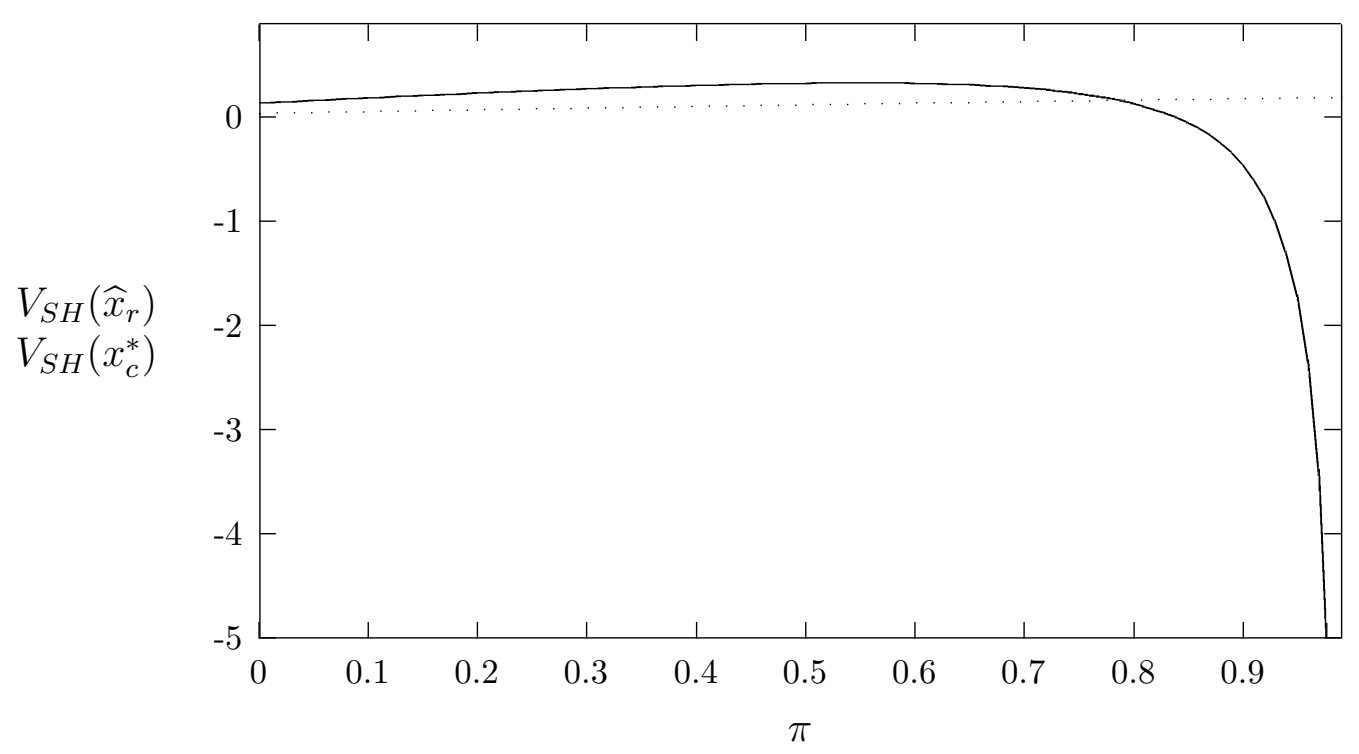

Figure 3: The continuous (dotted) curve represents shareholder value when entrenchment is (not) to be countered. Shareholders preempt entrenchment: $\pi^{*}=0.44$ and $\widehat{x}_{r}\left(\pi^{*}\right)=0.47$.

Notice that in both examples shareholder value is indeed maximized by countering managerial entrenchment (i.e., it is not optimal to set $\pi$ and $x_{r}$ below the $\widehat{x}_{r}(\pi)$ locus). Therefore, we can conclude:

Proposition 2 There is an open set of parameters for which shareholder value is maximized by countering managerial entrenchment, and hence by providing a minimal level of explicit stakeholder protection $\widehat{x}_{r}\left(\pi^{*}\right)>0$.

Remark 2 - Welfare effects - To be written. 


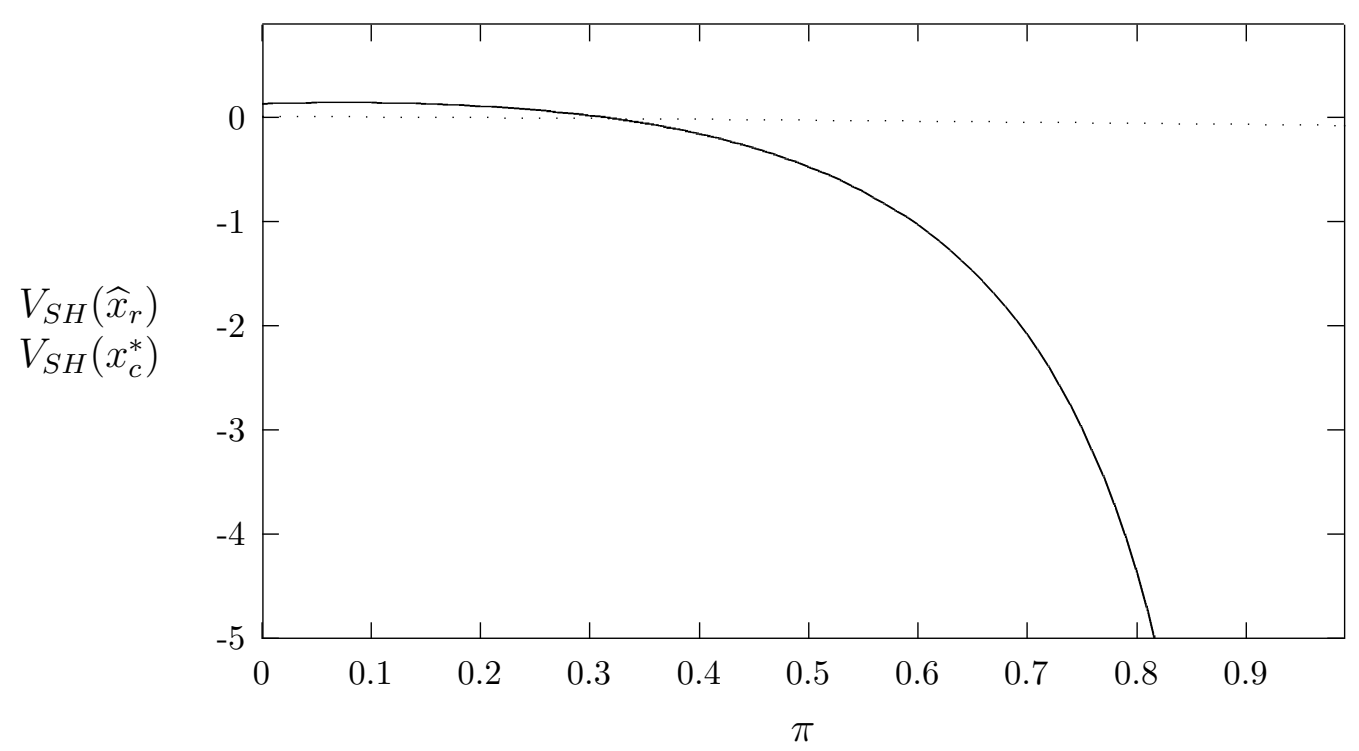

Figure 4: The continuous (dotted) curve represents shareholder value when entrenchment is (not) to be countered. Shareholders preempt entrenchment: $\pi^{*}=0.038$ and $\widehat{x}_{r}\left(\pi^{*}\right)=0.063$.

\subsection{Stakeholder welfare and managerial job security}

Stakeholders' welfare function changes according to whether $x_{r}$ and $\pi$ lie below or above the locus $\widehat{x}_{r}(\pi)$. By lemma 3, whenever $x_{r} \geq \widehat{x}_{r}(\pi), W_{S T}$ coincides with (1); hence, it is increasing in $x_{r}$ as well as $\pi$ : stakeholders can only benefit from the replacement of an inefficient manager. When instead $x_{r}<\widehat{x}_{r}(\pi)$, stakeholders' welfare writes as:

$$
\begin{aligned}
& W_{S T}\left(\pi, x_{r}\right)= \\
& \quad\left[\theta_{I}+\pi(1-a)\left(\theta_{R}-\theta_{I}\right)\right]\left[x_{r}+\left(1-x_{r}\right) \lambda\right] B+(1-\pi(1-a)) \theta_{I}\left(1-x_{r}\right)(1-\lambda) x_{c}^{*}\left(\pi, x_{r}\right) B
\end{aligned}
$$

which is also increasing in $\pi$ and $x_{r}$. Notice that the additional term with respect to (1) represents the benefit of managerial concessions: stakeholders now have a further motive for endorsing corporate governance rules that enhance managerial turnover, to the extent that the incumbent's concessions are an increasing function of $\pi$. Indeed, bad corporate governance rules allowing anti-takeover defenses and staggered boards make CEOs less eager to appeal to stakeholders, in that they do not need stakeholders' support to buttress their positions. This implies that even those stakeholders who would support incumbent CEOs in return for concessions prefer the firm's control to be contestable ex ante:

Corollary 1 Although stakeholder activists may want to side with the incumbent CEO at $t=1$, their welfare is always increasing in the quality of corporate governance rules enhancing 
managerial turnover.

Corollary 1 adds a further argument to The Economist's view on the use of anti-takeover defenses: "...who benefits from such protection against outside bids? Not shareholders, who lose their chance to vote on a change of management; and not employees or other stakeholders, whose interests may be better served by a new and more dynamic ownership. The only beneficiaries from obstacles to a market in corporate control are managers." ("Takeover Troubles," January 31st, 2002). Our result rationalize the recent, surprising interest of social and environmental activists for the corporate governance agenda. Many activists have in fact joined forces with small shareholders' lobbies to campaign against anti-takeover legislation, CEO-dominated boards and lenient auditors.

\subsection{CEOs}

Interestingly, inefficient CEOs have the opposite view of corporate governance and stakeholder protection rules. Indeed, lemma 3 implies the following result:

Corollary 2 The incumbent manager always benefits from a reduction in the intensity of the replacement threat and from a reduction in explicit stakeholder protection.

That CEOs may be opposed to tough competition in the managerial labor market is not surprising. Here we would rather stress that CEOs prone to make personal commitments to stakeholder representatives (which is the case whenever $x_{r}<\widehat{x}_{r}(\pi)$ ) are indeed opposed to welcome stakeholder-protection laws, or the introduction of explicit pro-stakeholder covenants in the firm's charter. This prediction is in line with casual evidence of managers who profess concerns for corporate social responsibility, but are then reluctant to endorse pro-stakeholder regulations and all "attempts to institutionalize considerations of stakeholder interests in corporate governance" (see Hellwig, 2000). ${ }^{17}$

\section{Applications and discussion}

\subsection{The political economy of corporate governance and legal stake- holder protection}

Our results can be applied to a political economy framework where interest groups (shareholders, incumbent managers and stakeholders) contribute to determine financial regulation

\footnotetext{
${ }^{17}$ Shleifer and Vishny (1989) informally argue that entrenchment objectives may explain why managers try to make the firm's contracts implicit rather than explicit.
} 
and legal stakeholder protection (e.g., labor protection, environmental regulation, antitrust enforcement, etc.). We then predict that besides endorsing a better corporate governance regime, small shareholders may want to support a minimal level of legal stakeholder protection to prevent the implicit agreement between inefficient managers and stakeholders. This is likely to occur when stakeholders' activism is effective but incumbent managers' private benefits of control are not too large (see example 1). In this case, shareholders' preferences over regulatory regimes are partially congruent with those of other stakeholders, in that both endorse corporate governance rules favoring managerial turnover and explicit stakeholder protection rules. ${ }^{18}$ We also predict that when instead stakeholder activism is very effective and incumbent managers' private benefits of control are very large, an "alliance" between small shareholders and incumbent managers arises at a political level. Both groups back corporate governance rules that leave CEOs' positions unchallenged and poor stakeholder legal protection, at the expense of stakeholder welfare. Such an alliance between shareholders and incumbent managers seems to be prevailing in the Italian political scene at the moment. On the one hand, neither labor nor environmental protection are a priority of the current legislature, as suggested by proposed reforms of the labor market and by recent laws on environmental liabilities. ${ }^{19}$ On the other hand, the security of managerial jobs has definitely not been impaired by recently-approved laws reducing charges for creative accounting practices.

\subsection{The optimal design of a corporate charter}

Our model can also help understand how stakeholders, shareholders and managers contribute to write or modify a firm's charter, whereby the organizational structure, the internal rules, and the allocation of control rights determine the quality of its corporate governance and the extent to which the firm commits to internalize stakeholder welfare.

Our results suggest that under some conditions, shareholders may want to pressure for a formal incorporation of socially responsible aims in the corporate charter, rather than leave a blank cheque to managers to promote shareholder value maximization or stakeholder protection at their convenience. This probably explains why some mainstream shareholder activists and institutional investors, having surrendered to the concept of corporate social responsi-

\footnotetext{
${ }^{18}$ In this respect, it will be interesting to see whether a minimal legal protection of workers, consumers and potential pollutees will still be enforced in case supporters of good corporate governance prevail in countries like Germany and France.

${ }^{19}$ The former aimed at reducing workers' guarantees against unjust dismissal, the latter substantially loosening the regulation on hazardous wastes.
} 
bility, are now pressuring CEOs and boards to produce timely information on environmental and social performance and to link executive compensation to these measures. 


\section{References}

Aghion, P. and J. Tirole (1997). Formal and Real Authority in Organizations. Journal of Political Economy 105(1), 1-29.

Ambec, S. and P. Barla (2001). A Theoretical Foundation of the Porter Hypothesis. Economics Letters (Forthcoming).

Baron, D. (2001). Private Politics, Corporate Social Responsibility, and Integrated Strategy. Research Paper n. 1656, Stanford Graduate School of Business.

Becker, B. (1995). Union Rents as a Source of Takeover Gains Among Target Shareholders. Industrial and Labor Relations Review (49), 3-19.

Bhagat, S., A. Shleifer, and R. Vishny (1990). Hostile Takeovers in the 1980s: the Return to Corporate Specialization. Brookings Papers on Economic Activity: Microeconomics.

Blair, M. (1995). Ownership and Control: Rethinking Corporate Governance for the Twenty-First Century. Washington: Brookings Institution.

Blair, M. and M. J. Roe (1999). Employees and Corporate Governance. Washington: Brookings Institution.

DeAngelo, H. and L. DeAngelo (1998). Ancient Redwood and the Politics of Finance: the Hostile Takeover of the Pacific Lumber Company. Journal of Financial Economics (47), 3-53.

Feddersen, T. and T. Gilligan (2000). Saints and Markets: Activists and the Supply of Credence Goods. Working paper, Northwestern University.

Hansmann, H. (1996). The Ownership of Enterprise. Harvard: Belknap.

Hellwig, M. (2000). On the Economics and Politics of Corporate Finance and Corporate Control. In X. Vives (Ed.), Corporate Governance, pp. 95-134. Cambridge: Cambridge University Press.

IRRC (2000). Social Policy Resolutions in 2000: Issues, Votes and Views of Institutional Investors. Technical report, IRRC.

Jarrell, G. A., J. Brickley, and N. Jeffry (1988, Winter). The Market for Corporate Control: the Empirical Evidence Since 1980. Journal of Economic Perspectives 2(1), 49-68.

John, A. and J. Klein (2001). The Boycott Puzzle: Consumer Motivations for Sacrifice. Working Paper, INSEAD. 
Pagano, M. and P. Volpin (2001). The Political Economy of Corporate Governance. CEPR Discussion Paper n. 2682.

Pagano, M. and P. Volpin (2002a). Managers, Workers and Corporate Control. Unpublished Manuscript, CSEF (Università di Salerno).

Pagano, M. and P. Volpin (2002b). The Political Economy of Finance. Oxford Economic Policy Review (forthcoming).

Perotti, E. and E. von Thadden (2002). The Political Economy of Bank versus Market Dominance. mimeo, University of Amsterdam and Université de Lausanne.

Porter, M. E. and C. van der Linde (1995). Toward a New Conception of the EnvironmentCompetitiveness Relationship. Journal of Economic Perspectives 9(4), 97-118.

Rosett, J. G. (1990). Do Union Wealth Concessions Explain Takeover Premiums? The Evidence on Contract Wages. Journal of Financial Economics (27), 263-282.

Shleifer, A. and R. W. Vishny (1988, Winter). Value Maximization and the Acquisition Process. Journal of Economic Perspectives 2(1), 7-20.

Shleifer, A. and R. W. Vishny (1989). Management Entrenchment. the Case of ManagerSpecific Investments. Journal of Financial Economics (25), 123-139.

Tirole, J. (2001). Corporate Governance. Econometrica 69, 1-35. 


\section{Appendix}

Proof of lemma 3 Define $\widehat{x}_{r}(\pi)$ as the level of environmental regulation such that $(2)$ holds as an equality:

$$
\widehat{x}_{r}(\pi)=\frac{[\Gamma-\Delta \theta(p+\tau)] \pi a-\lambda \tau \Delta \theta(1-\pi(1-a))}{(1-\pi)(1-\lambda) \tau} .
$$

Let $\Delta \theta=\theta_{R}-\theta_{I}$. By inspection of $(3), \widehat{x}_{r}(\pi)<1$ if and only if $\Gamma<\Gamma_{1}(\pi) \equiv \Delta \theta(p+\tau(1+\lambda))+$ $(\Delta \theta \tau(1-\pi) / \pi a)$ and $\widehat{x}_{r}(\pi)>0$ if and only if $\Gamma>\Gamma_{o}(\pi) \equiv(p+\tau) \Delta \theta+(\Delta \theta \lambda \tau(1-\pi(1-a))) / \pi a$. Notice that since $\lambda \in(0,1), \Gamma_{o}(\pi)<\Gamma_{1}(\pi)$.

Proof of proposition 1 Let $H_{1}=\Delta \theta(p+\tau(1-\lambda))$ and $H_{2}=\Delta \theta(1-a)(p+\tau(1-\lambda))+a \Gamma$ where $\Delta \theta=\theta_{R}-\theta_{I}$. If managerial entrenchment is to be countered, shareholder value writes as

$$
V_{S H}\left(\widehat{x}_{r}(\pi)\right)=\left(\frac{\theta_{I}+\pi \Delta \theta}{\Delta \theta(1-\pi)}\right)\left(H_{1}-\pi H_{2}\right)
$$

The first order condition for shareholder value maximization is given by

$$
\frac{\pi^{2} \Delta \theta H_{2}-2 \pi \Delta \theta H_{2}-\left(\theta_{I} H_{2}-\theta_{R} H_{1}\right)}{\Delta \theta(1-\pi)^{2}}=0 .
$$

Solving for $\pi^{*}$ we obtain

$$
\pi_{1,2}^{*}=1 \pm \sqrt{\frac{\theta_{R} a(\Gamma-\Delta \theta(p+\tau(1-\lambda)))}{\Delta \theta(a \Gamma+\Delta \theta(1-a)(p+\tau(1-\lambda)))}},
$$

if $\Gamma<\Delta \theta(p+\tau(1-\lambda))$, the discriminant is negative and $V_{S H}^{\prime}(\pi)>0$, for all $\pi \in(0,1)$. In this case shareholders always want to set $\pi$ as close to 1 as possible. Conversely, if $\Gamma>\Delta \theta(p+\tau(1-\lambda))$, the optimal level of corporate governance quality is given by

$$
\pi^{*}=1-\sqrt{\frac{\theta_{R} a(\Gamma-\Delta \theta(p+\tau(1-\lambda)))}{\Delta \theta(a \Gamma+\Delta \theta(1-a)(p+\tau(1-\lambda)))}} .
$$

Notice that $\pi^{*}$ is decreasing both in $a$ and $\Gamma$. 